\title{
Impact of Foreign Direct Investment on Economic Growth of Pakistan
}

\author{
Malik Khola Gul and Imran Naseem \\ COMSATS Institute of Information Technology, Department of Management Sciences, Abbottabad Pakistan
}

\begin{abstract}
The main purpose of this paper is to find and analyze the impact of FDI and trade openness on economic growth of Pakistan. For this study we used time series data from 2008-2013. Methods that are used for this purpose are co-integration analysis, regression analysis, correlation and Durbin Watson test which check the long run relation and association among variables. By using these test we examined that FDI, trade openness and domestic capital are positively effecting the economic growth as compared to other variable which is showing negative trend. Important essence of this paper is the requirement of policy reformulation and implication by the government of Pakistan that can be drawn from this paper finding. Government should take solid steps in order to increase FDI, exports and domestic investment and protect industries that would benefit the country's economic condition. Government should take measures in order to stabilize the exchange rate that may attract more investors for sake of higher profits. Higher FDI inflows in turns fetch more educated labour and replace the obsolete technology.
\end{abstract}

Key Words: Pakistan, economic growth, foreign direct investment

\section{Introduction}

Relationship between two factors Foreign Direct Investment and Economic Growth is a debateable topic among economist....from both empirical and theoretical perspective. Different studies have been carried out on finding the existing and causality among variables. Economic models are design to explore the dependency of one variable on other variables. For the host country functioning of FDI put forward its beneficiary image and positive impacts that foreign investment is a vital source of capital, complements domestic private investment, and is coupled with new job opportunities, knowledge sharing, competiton and improvement of technology transfer (obsolete the old one) that boosts overall economic growth in host countries.

Foreign Direct Investment is an international capital flow in which one country firm create a subsidiary in another country. It involves the acquisition rights and transfer of resources in host country. FDI and Economic Growth are treated as endogenous variables and are causes of each other and they have endogenous relationship. Economic Growth is driven by the ongoing openness of trade policies and FDI as well as the growth of international production is affected by economic and technological forces. Trade liberalization has provided an opportunity to developing countries for faster economic growth through trade and investment. FDI provides access to resources needed by developing countries like technology, capital, access to the markets, entrepreneurial abilities, managerial skills etc.

Economic performance and functioning is dependent upon different factors like debt, inflation, trade and domestic investment. Technological transfer, job creation, increased competition can results in attracting more FDI inflows in Pakistan and issue of saving and investment difference ratio is bridged by this opportunity.

Engine of Growth is generally referred to the International Free Trade. Export volume in free trade economy increases the demand of local products in outside world as a result local industries establish on large scale. FDI is the amount of share in host country economy and political stability which is most influential factor play a major role in increasing the share or inflow of money. A lot of studies have already been done on impact of GDP and FDI but still some variables are ignored. This study investigates that the FDI is not only the one factor for boosting the per capita GDP for Economic Growth but the trade openness seems positively affecting the growth phenomena. Trade openness not only talks about import and export but throwing light on government policies and regulations for free trade. This study seeks to discover the effects of proposed virtues of FDI hold for Pakistan's economy growth and also highlights the FDI contribution in Pakistan economy over the years.

Corresponding author: Imran Naseem, COMSATS Institute of Information Technology, Department of Management Sciences, Abbottabad Pakistan. Email: drimran@ciit.net.pk

cC This article is distributed under the terms of the Creative Commons Attribution License, which permits unrestricted use and redistribution provided that the original author and source are credited. 


\section{Objective}

The main objective of this study is to analyze the relationship and direction of FDI and economic growth...on different countries like developed, developing nations including Pakistan. For this objective study review different papers and conclude that either FDI has positive impact or negative impact on economic growth of host countries. Also quantify the effect of trade openness on FDI in Pakistan and suggest recommendation and policies for the government to attract more FDI in economy of country.

\section{Literature Review}

\section{FDI and Economic Growth}

FDI and Growth: What Causes What? By Abdur Chowdhury and George Mavrotas (Jan 2006) used Neoclassical growth model, Endogenous growth model and VAR model took GDP as dependent variable and FDI as independent variable. This research study used the test methodology of TodaYamamoto to exemplify the causality in economic growth and foreign direct investment. It is important for the policy formulation to explain the flow of causality from FDI to Growth is bidirectional or uni-directional for the attractiveness of investors in a country. For the investment FDI is not solely the driving factor but the human resource, government policies, taxes and infrastructure etc are the attractiveness factors in host country.

Foreign Direct Investment, Financial Development and Economic Growth by Niels Hermes and Robert Lensink (2003). They studied a different perspective of FDI impacts on host country, which FDI play a major role in uplifting of economic performance but on other side it depends a lot on circumstances of recipient country and situation differ country to country. Human capital and exports contribute its part in FDI growth of host country.

FDI and Host country Economic Growth..: Does the investor's country of origin play a role by Fabienne Fortanier (Aug 2007). This article study enlightens the FDI and country of origin impact on each other, origin country FDI is not an exact characteristic that FDI hold in role playing. In cross country comparison previous studies uses the micro level analysis and presents the more advanced attributes of FDI. TNC's organizational characteristics, technological levels seem more important for future research than competition base affects of one developed country than another developed one. "Bosworth and Collins" in (1999) presents the three dimensions for economic growth effected by FDI and TNCs (i-e) structural effects, technology and skill effects and size effects. Size means the investment and saving phenomena of host country and for production base which cause the growth effect.

The Role of FDI and Openness to Trade in Economic Growth by "Maria Beradovic and Jeanette Hennix"' (Jan, 2009). By using the Regression Growth Model for evaluation of results on sample of 82 countries with the help of statistical techniques of Regression analysis and Co-efficient of determination study showed the separated and combined effect of different explanatory variables on economic growth of countries and was quite unexpected results. Normally regression analysis demonstrates the positive relation between FDI, Trade Openness and Economic growth. These weaker results came may be due to some other factors that were neglected in model like Inflation, Taxes, and Human Resource etc.

“Shiva S. Makki and Agapi Somwaru (2004) emphasize on the previous studies regarding the FDI and Trade Openness positive and combine effect on Economic Growth and carried their research on 66 countries. Impact of other factors that has already been explained earlier can be different in magnitude from country to country and these factors explains the relationship either positive or a negative.

Financial Development and Economic Growth: A New Investigation a research conducted by Huiran Pan and Chun Wang (March, 2013). For examining the relationship between financial development and economic growth they applies the Bayesian Dynamic factor Model that was based on sampling technique of Vector Autoregression (VAR) with sample size taken from 89 countries. Using economic Growth as Dependent Variable and Financial Development as Independent Variable it is concluded that with the help of Bayesian model unobservable factors have been studied which drives both the financial development and financial growth of different income groups. Threshold income levels that exist in countries may interact with the economic activities which differently effect the financial development. Unobservable factors and variance decomposition analysis shows different results with different income level in countries. From 1970-2009 the unobservable factors traced the economic results which has showed the good fit for our estimation.

To exemplify the causality in economic growth and foreign direct investment it is important for the policy formulation to explain the flow of causality from FDI to Growth is bi-directional or unidirectional for the attractiveness of investors in a country. For the investment FDI is not solely the driving factor but the human resource, government policies, taxes and infrastructure etc are the attractiveness factors in host country. FDI and Trade Openness positive and combine effect on Economic Growth can be different in magnitude from country to country and these factors explains the 
relationship either positive or a negative. FDI play a major role in uplifting of economic performance but on other side it depends a lot on circumstances of recipient country and situation differ country to country. Human capital and exports contribute its part in FDI growth of host country.

Financial Development and Economic Growth: Another look at the evidence from developing countries by Yousif Khalifa Al-Yousif (Feb 2001). Causal relation between financial development and economic growth is bi-directional. The various studies shows that the relationships between variables are not generalized and are not applicable for cross border countries because every nation has its own economic policy and their economic growth depends on other factors. Financial Development of a country is dependent upon the respective economic policies of implementing institutions.

Impact of Foreign Direct Investment and Trade on Economic growth studied by Shiva S. Makki and Agapi Somwaru (Aug 2004) uses the 66 countries cross-section data. This study also contributes in explaining to the significance of FDI and Trade for Economic growth in developing countries. FDI is one way of attracting the advanced technology in country which in turn transfer our economy into more advanced economy and also positively uplift our domestic investment.

The Foreign Direct Investmen and Economic Growth Relationship: An empirical study on Malaysia conducted by Har Wai Mnu, Yee Kar Man and Teo Kai Lin (April 2008) using OLS Regression Model showing positive relation between FDI and Growth. For more employment in country government should encourage the foreign direct investment which directly boosts the economic condition. Effect of FDI can also be measured on host country economy by using export promotion strategy, property rights protection, and bureaucratic efficiency and many more. Results are gathered by taking GNI as dependent variable and FDI as independent variable, for rapid growth increase the FDI inflows in economy.

Basem Mohammed Louzi and Abeer Abadi (Aug 2011) studied The Impact of Foreign Direct Investment on Economic Growth in Jordan by applying the ECM and co-integration model to explain the relation of Dependent variable GDP and Independent variables FDI, Domestic investment and Trade liberalization. Result from these models attempted to explain the Direct Investment (DI) and Trade liberalization (TI) impact on GDP as positive growth relation and further flow of growth toward the FDI as whole. The causality of FDI toward GDP growth is not appropriate for Jordian economic growth so far and independently FDI inflows do not exert pressure alone. Further the study of Mottaleb (2007) was conducted on Determinants of FDI and its impact on economic growth of devel- oping countries also demonstrate how significantly FDI is important for economic growth.

Impact of foreign Direct Investment on Gross Domestic Product by Qaiser Abbas, Salman Akbar, Ali Shan Nasir, Hafiz Aman Ullah, Muhammad Akram Naseem (Aug 2011). Use the Regression Model on sample of 07 countries applying sampling technique of regression statistic. This study shows the flow of FDI toward the GDP progress but overall study highlights the significantly positive relation between FDI and GDP where as inverse relation between GDP and CPI (inflation). Other researchers has also found out the impact of FDI in relation to market share, domestic capital stock, stock exchange and applied different models on these variables and most of them showed positive relationship.

Foreign Direct Investment and Economic Growth conducted by Thirunavukkarasu Velnampy, Sivapalan Achchuthan and Rajendra Kajananthan (Dec 2013). In Srilankan context results that are extracted from regression analysis, granger causality test and co-integration test showed different outcomes that FDI and economic growth has less dependency on each other in a short run and little variance is countered among variables. In longer run equilibrium there exist positive relation between FDI and Growth rate.

Foreign Direct Investment, Financial development and Economic Growth: Empirical Evidence from North Africans Countries by Imen Mohamed Sghaier and Zouheir Abida (June 2013). Applying the GMM model on a sample of 4 countries for accessing the FDI and Financial development impact on Economic growth. Positive association has been found between FDI, FD and Growth where FD is carried by FDI and FDI growth led toward the better economic performance as well as growth. The Relationship and Direction of Causality between FDI and Economic Growth in Saudi Arabia by Hussain M. Al Obaid (Jan 2014). GDP as dependent variable and FDI as independent applied on Regression model over data period of 19852012. Saudi Arabia developed the interdependency among FDI and Economic Growth by attracting the massive FDI inflow as well as flourishing its economy. Saudi Arabia set the SAGIA and offers the fiscal and financial attractive policies for the investors who brought money in its economy. As a result national growth raises this increases the FDI inflow.

In summary, the studies shows that the relationships between variables are not generalized and are not applicable for cross border countries because every nation has its own economic policy and their economic growth depends on other factors. Financial Development of a country is dependent upon the respective economic policies of implementing institutions. FDI is one way of attracting the advanced technology in country which 
in turn transfer our economy into more advanced economy and also positively uplift our domestic investment. Effect of FDI can also be measured on host country economy by using export promotion strategy, property rights protection, and bureaucratic efficiency and many more. The significantly positive relation between FDI and GDP where as inverse relation between GDP and CPI (inflation) has been observed

\section{Pakistan's Research Perspective}

\section{FDI and Economic Growth}

Foreign Direct Investment and Economic Growth: The Role of Domestic Financial Sector by Muhammad Arshad Khan (2007). Analysis report of this research paper is based on advanced testing approach of Pesaran, et al (2001) which is Bound testing approach, suggests a country to liberalise its economy need to develop a positive relation between FDI and Growth where as financial sectors of Pakistan also benefited from it. To take advantage of both long and short run from positive relation Pakistan should have private sector credit rating greater than real GDP by some specific percentage. From the domestic development not only the foreign investors show willingness to invest but also having foreign investment benefits. Domestic financial investment is a requisite of higher FDI which exhibit a positive relation for economic growth.

A Nexus between Foreign Direct Investment and Pakistan's Economy by Muhammad Zahid Awan, Bakhtiar Khan, Khair uz Zaman (2010). Data is estimated by Augmented Dickey Fuller (ADF) and ECM (error correction model). Suggested in order to attract more foreign investors government need to take solid steps by offering incentives, ensuring stable exchange rate for increment of FDI inflows in economy. Fluctuating inflation rate or CPI seems smart strategy for inducing more investors because more the price levels more will be the profit margin. Recently macroeconomics stability in Pakistan indicates negative Current Deficit Account (-1.7661) but improved Balance of Payment.

Impact of Foreign Direct Investment on Economic Growth: A case study of Pakistan by Amna Muhammad Gudaro, Imran Umer Chhapra, Salman Ahmed Sheikh (2010). FDI, GDP and Inflation (CPI) relation is explained by using multiple regression model. Article found out the positive relationship in GDP and FDI and negative phenomena in GDP and Inflation. FDI led growth of economical condition of Pakistan but it requires the policy implication by government to attract and retain more and more investors. FDI invite the prosperity in country like obsolete technology is replaced by advanced one, domestic industries flourish as a result of competition by producing quality goods for survival in market. Tax revenues contribute to the profit maximization in host country.

Foreign Direct Investment and Economic Growth in Pakistan: A Sectoral Analysis by $\mathrm{Mu}-$ hammad Arshad Khan and Shujaat Ali Khan (2011). Applying panel co-integration over sample data, it is assessed that FDI and real output are counter dependent and their impact on sector specific. Causality relationship flow from FDI to GDP and is observed uni-directional in long-run and vice-versa for short-run in a sector level. In manufacturing sector, where relationship flow is reverse in order that uni-directional relation flow from GDP to FDI. In service sector, causality show FDI run toward output in uni-directional flow.

The causal link between Foreign Direct Investment and Economic Growth in Pakistan by Najid Ahmed, Muhammad Farhat Hayat, Muhammad Luqman, Shafqat Ullah (2012). This study uses two models named ECM and COINTEGRATION model for showing the FDI relation with GDP. GDP is taken as indicator of economic growth and GDP increased by Foreign Direct Investment. If Pakistan want to achieve high economic growth policies reformulation is severely needed to attract high investment portfolio into country. The positive relation exist in both long and short run and there is also a positive relation between FDI and Political stability, instability can harm the foreign investment and country will face the decline in economic performance otherwise.

The Impact of Foreign Direct Investment on Pakistan Economic Growth by Kashif Yasin and Dr. Muhammad Ramzan (March 2013). In this paper researcher tries to explore the Trade volume (import + export) and FDI development for Pakistan as well as GDP growth. Economic Growth can b achieved if exports volume increases against imports, facilitating domestic human capital through technological advancement. Long-short run relationship is explained by Auto Regressive Distributed Lag model using secondary data from different sources.

Impact of Foreign Direct Investment on Economic Growth of Pakistan by Dr. Najia Saqib, Maryam Masnoon and Nabeel Rafique (2013). This article is different from previous studies reveal the negative impact of FDI on economic performance but benefitted from domestic investment performance. Other factors that brought negative impact are trade, CPI, government debt on Pakistan economy. Negative impact is due to reason that FDI competition creates suppressing of domestic natural resources and monopoly ruled by industrial sector.

The Determinants of Foreign Direct Investment in Pakistan: An Econometric Analysis is examined by Mohammad Hanif Akhtar (2000) uses the analysis of multivariate regression and find out the major determinant of FDI is market size irre- 
spective of market fluctuation in exchange rate and interest rate. Other market variables such as political instability, goods import etc are considered insignificant for this study.

Determinants of Foreign Direct Investment in Pakistan over the period 1975-2011 by Muhammad Umar Farooq, Dr. Hazoor Muhammad Sabir, Safdar Hussain Tahir, Muhammad Kashif Rasheed (2012). Like previous researches they stated same observation of improvement in GDP ratio rather to invest on infrastructure alone for attractiveness of FDI. Use resources in positive way so as to increase the overall output and enhanced GDP increase the inflows FDI in Pakistan. Maintain the level of exchange rate as well as the policies of fiscal and monetary.

Foreign Direct Investment in Telecommunication Sector of Pakistan: An Empirical Analysis by Shumaila Hashim, Akhtar Munir, Afnan Khan (Jan 2009). They studied different variables and present their result in a way that variables are strongly impacting the role of FDI in telecommunication sector and variables are literacy rate, market share, size, internal competition and per capita income.

The Role of FDI on Stock Market Development: The case of Pakistan by Ali Raza, Nasir Iqbal, Zeshan Ahmed, Mohammad Ahmed, Tanvir Ahmed (Jan 2012) present their finding which are related to previous researches of showing upward shifting of graph of Stock Market Development by enhancement of Domestic Saving. Whereas FDI shows a upward growth and positive relation with stock market development.

Impact of Foreign Capital Inflows (FCI) on Economic Growth in Pakistan by Ghulam Moheyud-din (June 2006) explained quite positive impact of FCI on GDP in Pakistan by increasing the financial and industrial sectors, provide them more advanced technology, and assist them in correcting budget deficit and balance of payment.

The Impact of FDI on Economic Growth under Foreign Trade Regimes: A case study of Pakistan by Zeeshan Atique, Mohsin Hasnain Ahmad and Usman Azhar (2004) showed the FDI enhancement by using the export promotion strategy rather than import substitution. As Pakistan is open economy, it can increase FDI through foreign capital inflows and domestic saving as well.

Impact of Foreign Direct Investment on GDP: A case study from Pakistan by Nadeem Iqbal, Naveed Ahmed, Zeeshan Haider, Sonia Anwar (2014) found positive association and stated not only FDI inflow is impacting factor but in case when following market oriented policies. FDI is cultural and situational its benefits cannot be assumed before time.

The Causal link between FDI and Economic Growth in Pakistan Economy by Muhammad Irfan Javaid Attari, Dr.Yasir Kamal, Sumayya Nasim Attaria (Jul, 2011). They add valuable information to this research by explaning less attractiveness of FDI in Pakistan. GDP or total output of our economy is not stable and developed for the assurance of investors. Political issues create main hurdle in less investment in Pakistan other than this Pakistan's economic crises are also not appealing because of loan tendency from IMF, World Bank etc. It throws light on negative aspects of high interest level and currency fluctuation.

Determinants of FDI in Pakistan's Agriculture Sector by Zeeshan Anwar, Rashid Saeed, M. Kaleem Khan, Syedah Shan-E-Ahmad (2013). This study is about FDI association with GDP and Trade Openness. Positive relation has been explored between GDP and FDI where as negative sign for government debt. Furthermore, other variables like price changes which is inflation has positive sign with FDI and negative with exchange rate for agriculture sector.

Impact of Exchange Rate on FDI in Pakistan by Muhammad Bilawal, Muhammad Ibrahim, Amjad Abbas, Muhammad Shuaib, Mansoor Ahmed, Iltaf Hussain, Tehreem Fatima (2014). For given time period data shows effects of exchange rate fluctuation over inflow FDI. It shows strongly positive association between exchange rate and FDI because higher the exchange rate for foreigners more will be their profits and more will be the chances of investment.

GDP is taken as indicator of economic growth and GDP increased by Foreign Direct Investment if Pakistan wants to achieve high economic growth policies reformulation is severely needed to attract high investment portfolio into country. Domestic financial investment is a requisite of higher FDI which exhibit a positive relation for economic growth. In order to attract more foreign investors government need to take solid steps by offering incentives, ensuring stable exchange rate for increment of FDI inflows in economy. Negative impact is due to reason that FDI competition creates suppressing of domestic natural resources and monopoly ruled by industrial sector. Political issues create main hurdle in less investment in Pakistan other than this Pakistan's economic crises are also not appealing because of loan tendency from IMF, World Bank etc. It throws light on negative aspects of high interest level and currency fluctuation. Positive relation has been explored between GDP and FDI where as negative sign for government debt.

\section{Research Methodology}

This article investigates The Impact of FDI on Economic Growth of Pakistan, this research is quantitative based and data is quantified by using different tests. A model is designed to access the variables like domestic capital, labour force, FDI, export growth and their impact on economic performance of a country. Secondary data is used for 
this research and Borensztein (1998) and Kumar and Pardhan (2002) research model has been adopted and adjusted according to variables.

There are other statistical models that are used to analyze the determinants of economic growth like Solow's production framework model. Two variables are GDP (total aggregate output) and FDI are taken for analysis...further dependent and independent variables are classified in two categories. This study has used data of time period 2008-2013 i-e 06 years, taken from Handbook of Statistic on Pakistan Economy issued by State Bank of Pakistan statistical bulletin (statistical summary for session as well as comparison with previous year) and previous financial reviews.

\section{Time Series Data}

We have time series data of 06 years ranging from year 2008-2013 taken from secondary source of State Bank of Pakistan, and by studying previous papers. Data selection is based on Pakistan econo- my and its economic sectors. I have selected 06 years in order to evaluate FDI inflows/outflows fluctuation and its impact on overall economy in this time period as compared to previous years. Normally time series data show the property of non-stationary in levels which will be analysed through co-integration analysis. .

Dependent Variable. GDP (Gross Domestic Product) is a dependent variable and which is endogenous variable written on left side of equation.

Independent Variable. Exogenous variables for this research study are Domestic Capital (K), Labour Force (L), Foreign Capital (FDI), and Total Exports (X) written on right side of equation.

\section{Theoretical Framework}

This theoretical framework shows the relationship between dependent variable and independent variable i-e GDP is dependent on different variables like foreign capital, labour force, exports, domestic capital.

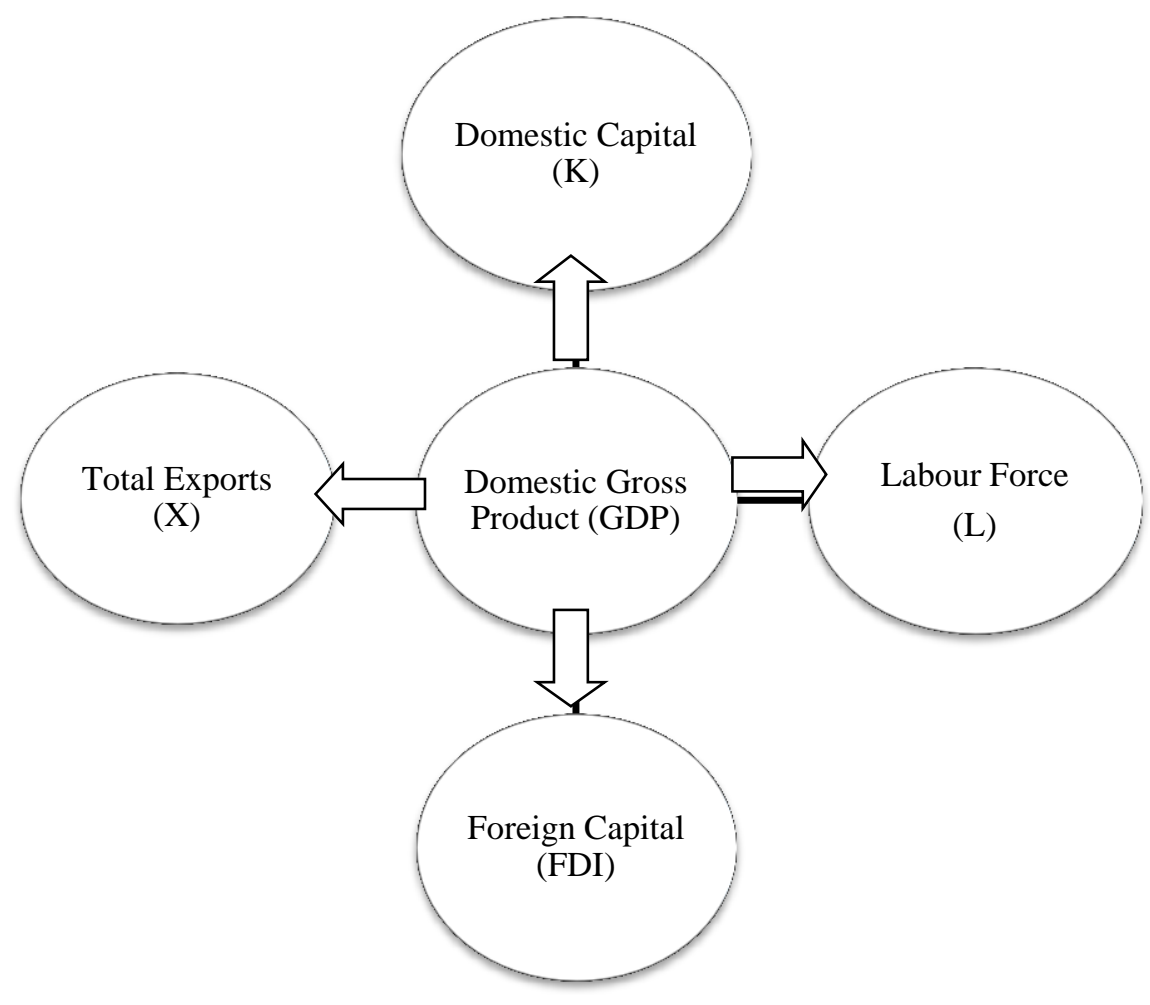

\section{Gross Domestic Product}

Gross Domestic Product (GDP) is actually the measure of overall economy's expenditures and output. GDP in real terms is a national income contributing towards economic growth by viewing the number of domestic products produces from do- mestic resources. In given below figure data of previous years GDP showed a upward growing trend in economy consistently from 2002 to 2006. Present study is intended to investigate the GDP contribution for economy boosting from 2006 to onward. 


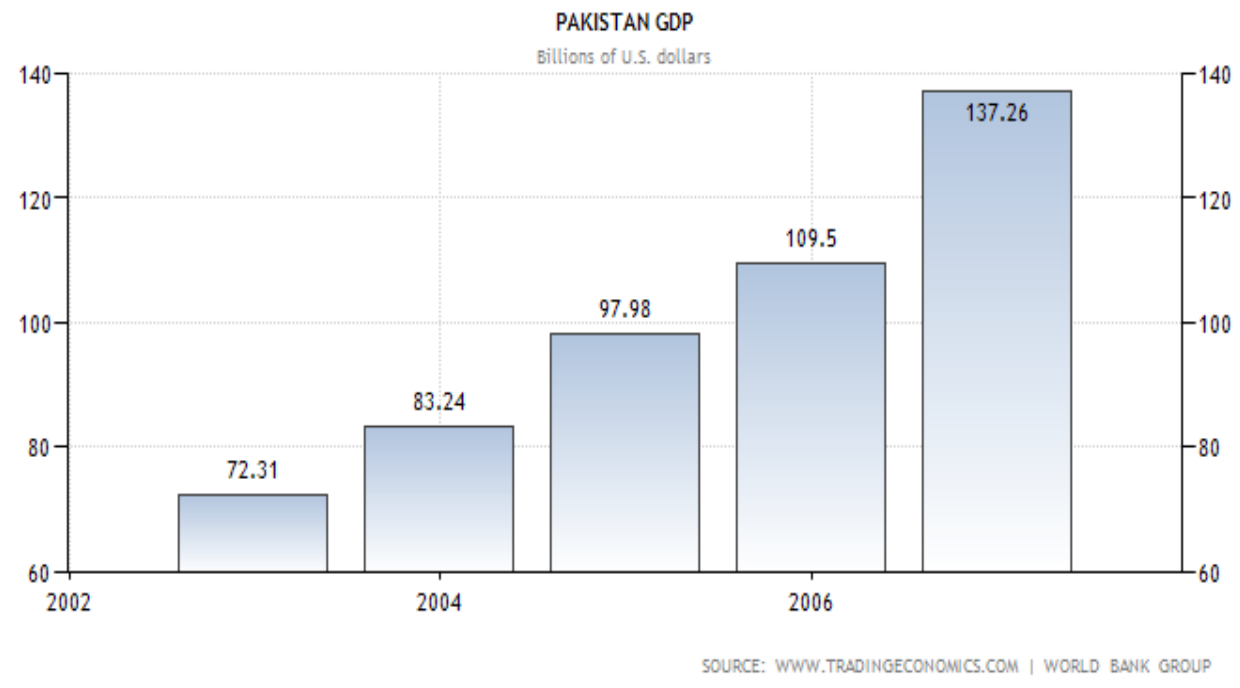

\section{Labour Force}

Labour force is the supply of labour services for the production of goods during a stipulated time period. It includes both employed and unemployed labour. When all labour force is fully employed the output ratio increase with appropriate allocation of resources. Labour force is sum of two components i-e population growth rate and employment opportunities

\section{Domestic Capital}

Domestic capital is the gross capital formation and is measure of fixed capital formation. Fixed assets are machinery, equipments, roads, railways, schools etc. Capital assets can be increased by both private and public sectors.

\section{Foreign Capital}

Foreign capital is amount of inflows through foreign direct investment in form of holding more market shares by foreign investors. Foreign investors buy our local assets and domestic residents also. Foreign capital shows the balance of payment recording positive balance on capital account.

\section{Exports}

Exports are the shipment of goods and services from homeland to the rest of the world where exports products are demanded. In this secondary approach export data will also be considered for economic growth. As our exports increases our foreign reserves will definitely increases.

\section{Hypothesis Development}

- H1: There is a positive relation between GDP and Domestic capital for Economic growth of country. (Null Hypothesis $\mathrm{H}_{0}$ : $\mathrm{b}_{1}=0$, Alternate Hypothesis $\mathrm{H} 1: \mathrm{b}_{1}>0$ )

- H2: There is a positive relation between GDP and Labour force for Economic growth of country. (Null Hypothesis $\mathrm{H}_{0}$ : $\mathrm{b}_{2}=0$, Alternate Hypothesis $\mathrm{H} 1: \mathrm{b}_{2}>0$ )

- H3: There is a positive relation between GDP and Foreign capital for Economic growth of country. (Null Hypothesis $\mathrm{H}_{0}$ : $\mathrm{b}_{3}=0$, Alternate Hypothesis $\mathrm{H} 1 \mathrm{~b}_{3}>0$ )

- H4: There is a positive relation between GDP and Total exports for Economic growth of country. (Null Hypothesis $\mathrm{H}_{0}$ : $\mathrm{b}_{4}=0$, Alternate Hypothesis $\mathrm{H} 1: \mathrm{b}_{4}>0$ )

For justifying the given hypothesis we used the ttest that shows the relation between regressor and regressond. T-test is selected because standard deviation is un-known, and t-test tells about data follows the normal distribution also calculate variance of distribution.

\section{Equation for Model}

$\ln \mathrm{GDP}=\mathrm{b}_{0}+\mathrm{b}_{1}, \ln \mathrm{K}+\mathrm{b}_{3} \ln F D I+\mathrm{b}_{4} \ln \mathrm{L}+\mathrm{b}_{5} \ln \mathrm{X}+\mu$ GDP $=$ Gross Domestic Product

$\mathrm{K}=$ Domestic Capital

$\mathrm{L}=$ Labour Force

FDI= Foreign Direct Investment

$\mathrm{X}=$ Total Exports

$\mu=$ Error Term (un-observable factors)

\section{Data Analysis (Econometrics Techniques)}

Regression Analysis. Regression checks the dependency of one variable on other using linear relationship model.

Correlation Coefficient . Correlation Coefficient sees the extent of association between the dependent variable and explanatory variable.

Durbin Watson Test. Durbin Watson test the correlation between residuals in time series data. DW 
test ranges from 0-4. This identifies the level of serial correlation among residuals and residuals are un-correlated if it is less than 2.

Data used here in this study is based on secondary source completely. Data is collected from State Bank of Pakistan website, financial reviews and Board of Investment websites.

\section{Results}

Table: 1

\begin{tabular}{|r|r|r|r|r|r|}
\hline Years & \multicolumn{5}{|l|}{ Independent variable } \\
\hline & GDP (million) & Foreign Capital (FDI) (M) & Domestic Capital(K) & Total Exports(X) (M) & \multicolumn{1}{c|}{ Labour (K) } \\
\hline 2008 & 152390 & $378,686.00$ & $3.83 \%$ & 938,428 & 50450 \\
\hline 2009 & 170080 & $291,974.95$ & $-11.96 \%$ & $1,147,435$ & 52860 \\
\hline 2010 & 167870 & $173,784.64$ & $-6.09 \%$ & $19,290,034$ & 53760 \\
\hline 2011 & 177170 & $139,775.40$ & $-6.26 \%$ & $24,810,422$ & 54400 \\
\hline 2012 & 213690 & $73,222.14$ & $1.48 \%$ & $23,624,256$ & 55800 \\
\hline 2013 & 224880 & 140863.01 & $0.78 \%$ & $12,024,295$ & 56920 \\
\hline
\end{tabular}

Data collected for this paper is from website of State Bank of Pakistan, Board of investment, Financial reviews, Trading Economies. Scaling variable used here is \$million but later on conerted into rupee million, $\mathrm{K}$ is presened in \%age. For data analysis we converted them intopercentages.

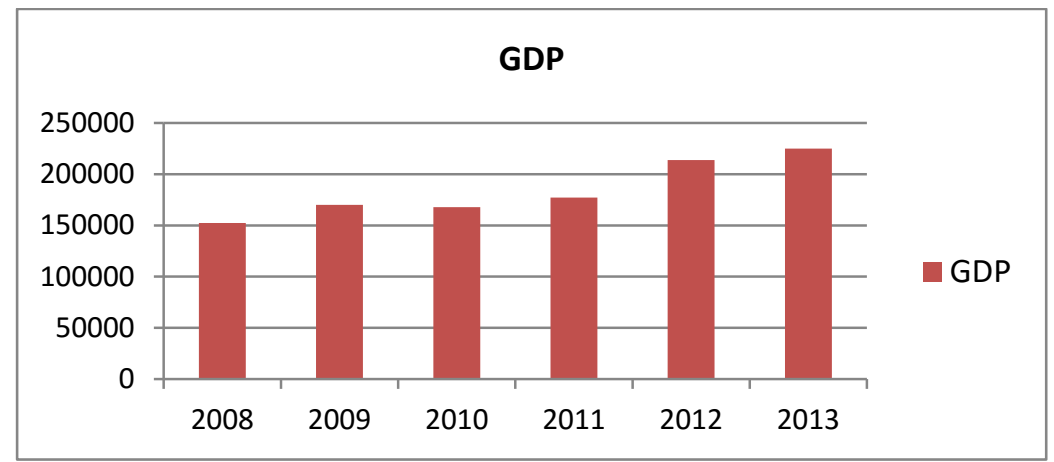

Graph: 1. GDP

\section{Gross Domestic Product}

The Gross Domestic Product (GDP) in Pakistan was worth 224880 million rupees in 2013. The
GDP value of Pakistan represents 0.38 percent of the world economy. GDP in Pakistan reaching an all time high of 224880 million rupees in 2013 and a record low of 152390 million rupees in 2008.

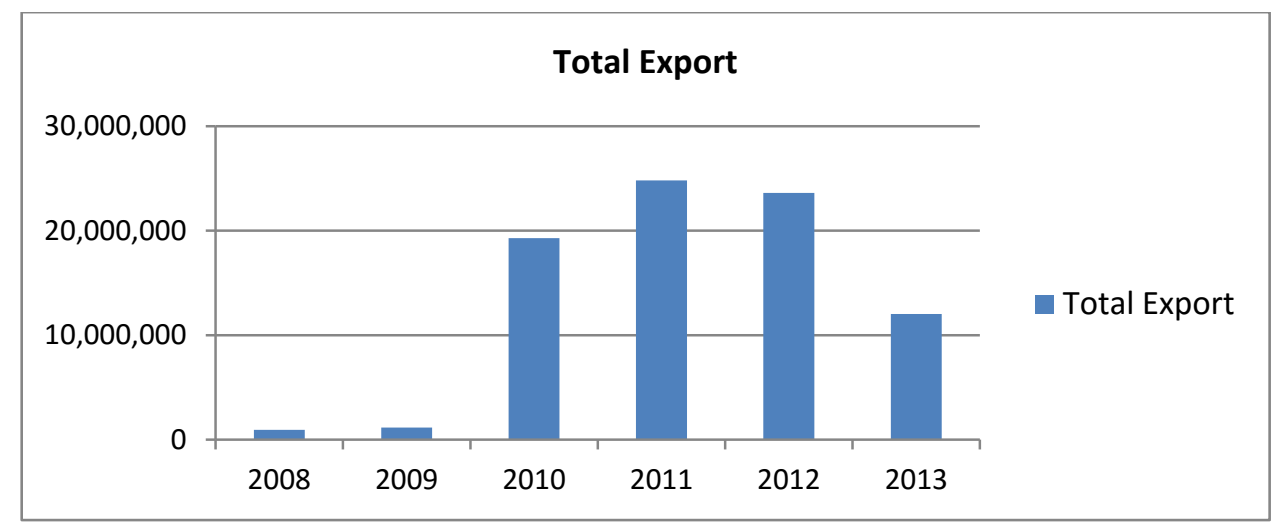

Graph: 2. Total Export 


\section{Exports}

Exports in Pakistan reaching a high time of 24810422 PKR Million in 2011 and a record low of
938428 PKR Million in 2008. Again it show decreasing trend in 2012 and 2013 after increasing in 2011.Exports in Pakistan is reported by the Pakistan Bureau of Statistics.

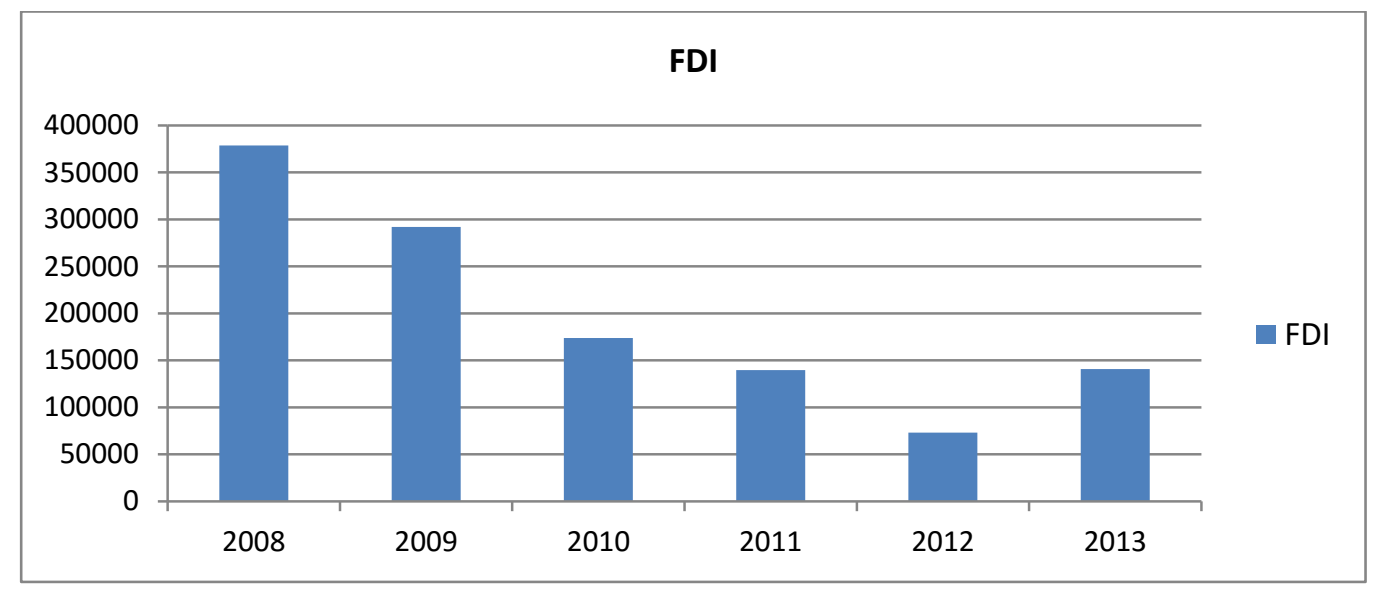

Graph: 3. Foreign Direct Investment

\section{Foreign Direct Investment}

Foreign capital is amount of inflows through foreign direct investment in form of holding more market shares by foreign investors. Foreign investors buy our local assets and domestic residents also. Foreign capital shows the balance of payment recording positive balance on capital account. FDI in Pakistan showing increasing trend in 2008 of 378686 million and lowest record in 2012 of 73222.138 million again showed upward movement in 2013 which is 140863.01 million.

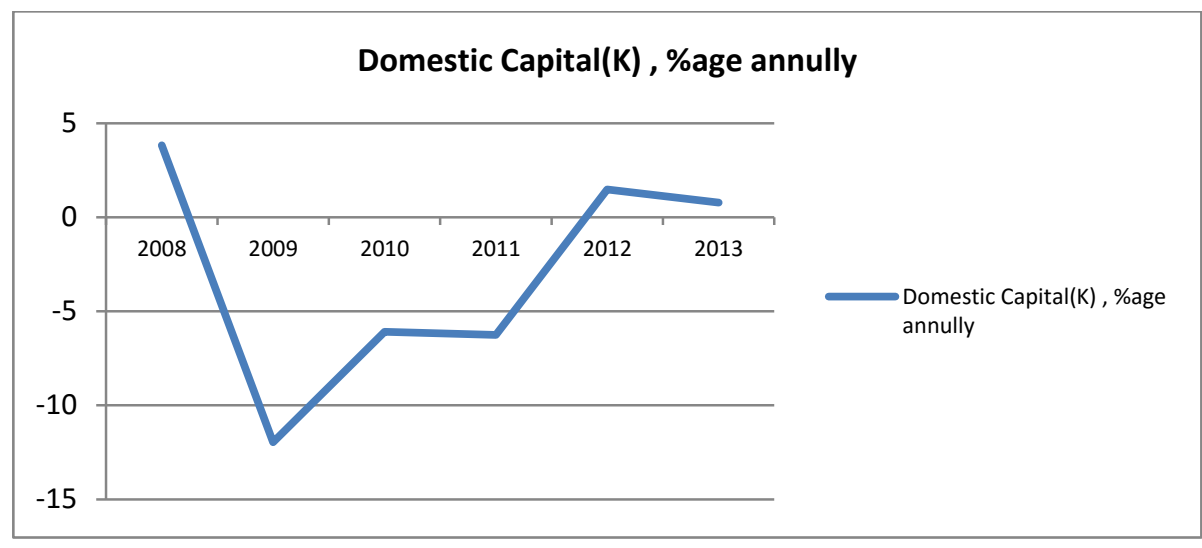

Graph: 4. Domestic capital

\section{Domestic Capital}

Gross Fixed Capital Formation in Pakistan decreased to 1307698 PKR Million in 2013 from 1362100 PKR Million in 2012. Gross Fixed Capital Formation in Pakistan averaged 1427559.89 PKR
Million from 2006 until 2013, reaching an all time high of 1569742 PKR Million in 2008 and a record low of 1307698 PKR Million in 2013. Gross Fixed Capital Formation in Pakistan is reported by the State Bank of Pakistan. 


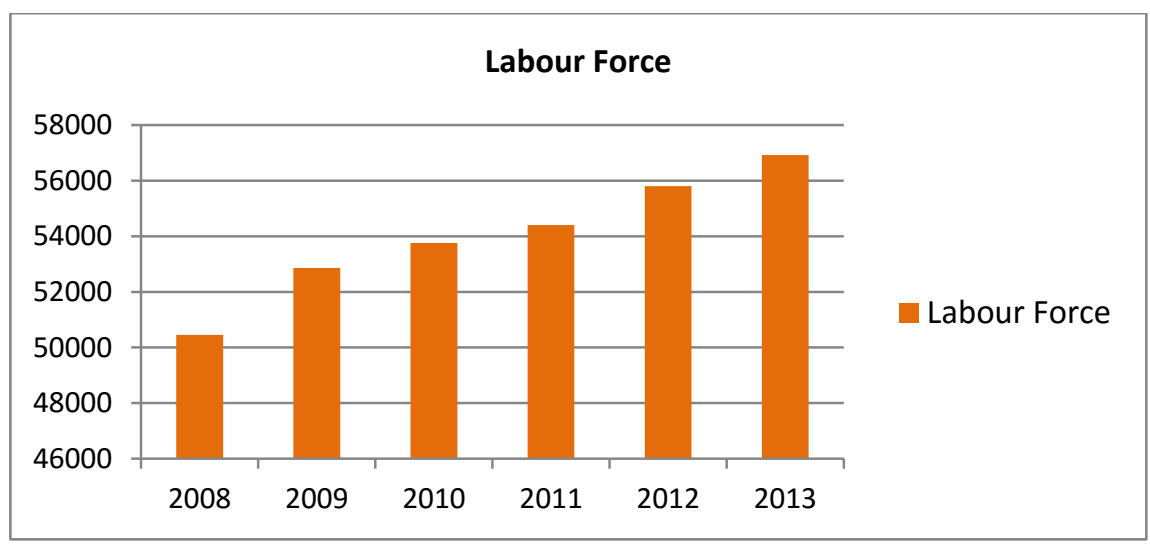

Graph: 5. Labour force

\section{Labour Force}

The number of employed persons in Pakistan increased to 56920 Thousand in 2013 from 55800 Thousand in 2012. Employed Persons in reaching an all time high of 56920 Thousand in 2013 and a record low of 50450 Thousand in 2008. Employed Persons in Pakistan is reported by the State Bank of Pakistan.

Results and Discussion

Table: 2.

Coefficients $^{a}$

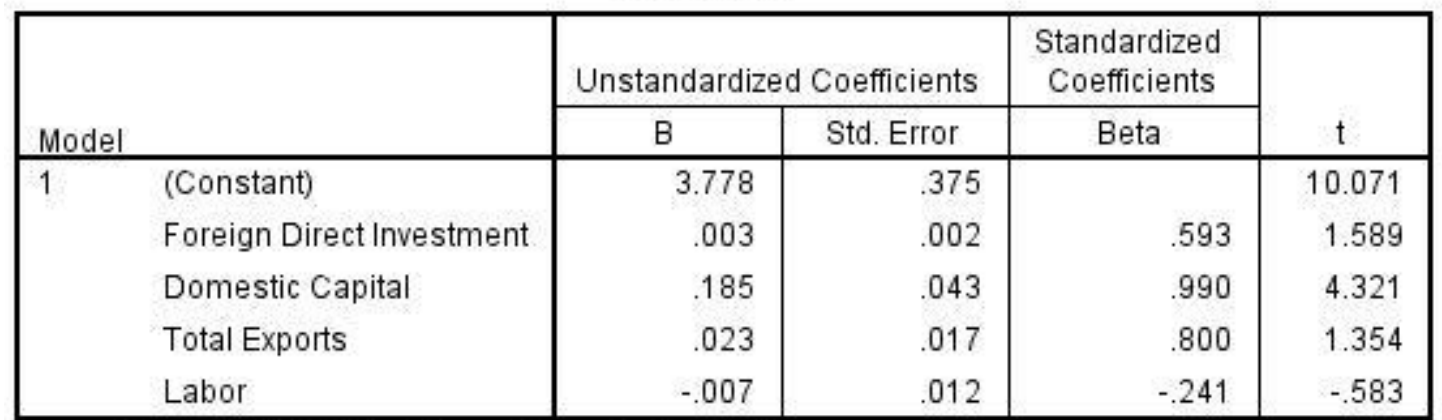

a. Dependent Variable: Gross Domestic Product

\section{Correlation Coffecient}

Significance level of the coefficients is assured by using t-test. Variables are significant at $5 \%$ in our study variables are showing negative values less than $5 \%$ which means there is no dependency of dependent variable on independent variable. Stated null hypothesis there is positive significant relation between GDP and FDI, Domestic Capital and Total Exports which means exports contributes more in economic growth and increases our foreign reserves as well as investment from foreign and domestic firms also.

FDI is perfect significant showing correlation of 1.58 between dependent variable and independent. Trade openness is 1.35 positive and significantly effecting the economic growth. Domestic capital
4.3 is also positively related with dependent variable and contributing into growth of GDP. All variables are significant at $5 \%$ in model. Our null hypothesis which is " $H_{0:}$. There is a positive relation between FDI, Domestic capital and total exports" is accepted. All variables are showing positive impact on dependent variable. Beta is showing how much change occur in dependent variable by changing one unit of independent variable. FDI is showing positive correlation when one unit change occur in FDI would bring 59\% increase in overall economy. Same goes for Domestic capital where one unit change bring 99\% increase in economy and same for Exports which increases overall economy by $80 \%$. Labour is negatively effecting the GDP growth by $24 \%$ decrease. 
Table: 3. Model summary

\begin{tabular}{|c|c|c|c|c|c|c|}
\hline \multicolumn{7}{|c|}{ Model Summary ${ }^{b}$} \\
\hline \multirow[b]{2}{*}{ Model } & \multirow[b]{2}{*}{$\mathrm{R}$} & \multirow[b]{2}{*}{ R Square } & \multirow[b]{2}{*}{$\begin{array}{l}\text { Adjusted R } \\
\text { Square } \\
\end{array}$} & \multirow[b]{2}{*}{$\begin{array}{l}\text { Std. Error of } \\
\text { the Estimate }\end{array}$} & Change ... & \multirow[b]{2}{*}{$\begin{array}{l}\text { Durbin- } \\
\text { Watson }\end{array}$} \\
\hline & & & & & $\begin{array}{l}\text { R Square } \\
\text { Change }\end{array}$ & \\
\hline 1 & $.979^{a}$ & .958 & .789 & .51768 & .958 & 1.382 \\
\hline
\end{tabular}

a. Predictors: (Constant), Labor, Domestic Capital, Foreign Direct Investment, Total Exports

b. Dependent Variable: Gross Domestic Product

\section{Regression}

Regression analysis summary results in table 2 explain the accurate model dependency and influence of independent variable on independent. Strength and weakness of relationship of independent variable is determined by value of $\mathrm{R}$ square. If it is less than $50 \%$ it means weak relation exist in model and if not than it means strong relation hold. The coefficient of determination $\mathrm{R}$ square shows that the explanatory variables are explaining total variation of $95 \%$ in dependent variable which is GDP by its predicators which are labor, domestic capital, foreign direct investment, total exports and model is perfectly strong.

\section{Durbin Watson Test:}

Durbin Watson tests the correlation between residuals in time series data. DW test ranges from 0-4.
This identifies the level of serial correlation among residuals and residuals are un-correlated if it is less than 2. In this model of regression the residuals are 1.382 which is not serially correlated means increase or decrease in one term does not affect the other variables. Effects can be measured individually on the dependent variable.

\section{Graphical Representation:}

Graph explains the variation trend in data and presenting positive relation between two variables. At GDP 4.9 the FDI is positively moving at $20.04 \%$ in year 2008 but as we move on further GDP and FDI showing negative relation in 2009(-22.89), 2010(537.84), 2011(19.57) and 2012(-47.61) all having negative trend in FDI with GDP. Again in 2013 FDI tend to move upward on positive side at $92.30 \%$ with GDP at level of 3.70 .

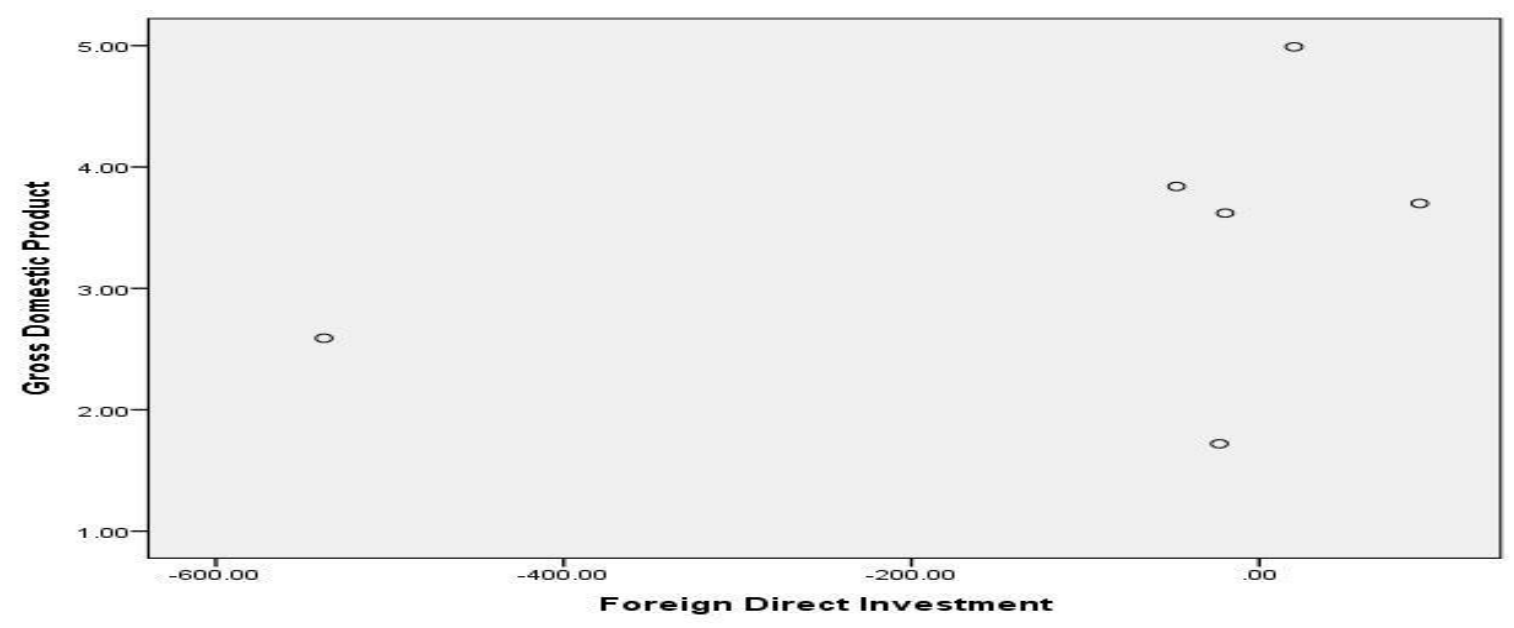

\section{Conclusion}

This paper examined the impact of FDI on economic growth from time period of 2008-2013. In literature reviews most of research articles showed positive relation between FDI and growth. This paper use different statistical test to analyze this effect like previous studies this paper findings suggest that FDI is not the only factor causing economic growth but trade liberalization and domestic capital playing positive role for escalation.
Cointegration technique is used to show the long run relation among variables positively as well as significantly. Exports during this time period shows positive and significant long run relation with GDP where as Labour is showing negative trend but is considered significant for growth. . FDI and Domestic capital are also throwing light on positive aspects of variables for accelerating economic growth.

In regression analysis the Durbin Watson test is applied for checking the correlation between residuals in time series data. DW test ranges from 
0-4. This identifies the level of serial correlation among residuals and residuals are un-correlated in this model at 1.38 which is not serially correlated means increase or decrease in one term does not effect the other variables. Effects can be measured individually on the dependent variable. . The coefficient of determination $\mathrm{R}$ square shows that the explanatory variables are explaining total variation of $95 \%$ in dependent variable which is GDP by its predicators which are labor, domestic capital, foreign direct investment, total exports and model is perfectly strong.

\section{Recommendations}

Important essence of this paper is the requirement of policy reformulation and implication by the government of Pakistan that can be drawn from this paper finding. As in this FDI is considered much significant for growth like other variables like exports and capital formation. But FDI relation with economy growth can be intermediated by several other variables like human resource capital that having original influence on creating relationship between GDP and FDI in country. Pakistan is a resource abundant country can take advantage from domestic capital formation.

Government should take solid steps in order to increase foreign as well as domestic investment and protect industries that would benefit the country's economic condition instead of totally relying on foreign investment and aids. Incentives and relaxation should pursue for foreign investors so that they likely to invest in our country instead to investing some other country. When our Dross Domestic Products goes on increasing our total output would definitely goes up because GDP is the measure of size of economy using its own natural resources. Government should take measures in order to stabilize the exchange rate that may attract more investors for sake of higher profits. Higher FDI inflows in turns fetch more educated labour and replace the obsolete technology.

\section{References}

Abdur, Ch, George M (2006) FDI and Growth: What Causes What? Chile.

Fabienne F. (2007) FDI and Host country Economic Growth...: Does the investor's country of origin play a role? Netherlands.

Maria B and Jeanette H (2009) The Role of FDI and Openness to Trade in Economic Growth. Sweden.

Huiran P and Chun W (2013) Financial Development and Economic Growth: A New Investigation. Vol 38. Number 1. March 2013. Fullerton, USA.

Basem L.M. and Abeer A (2011) The Impact of Foreign Direct Investment on Economic Growth in Jordan. Vol 8. Issue-2. Jordan.
Shiva M.S. and Agapi S (2004) Impact of Foreign Direct Investment and Trade on Economic Growth. Washington, DC 20433, USA.

Yousif AY. K. (2001) Financial Development and Economic Growth: Another look at the evidence from developing countries. Pp. 131-150. Abu Dhabi, UAE.

Har, M. W. M. K. Yee and L. K. Teo (April 2008) The FDI and Economic Growth Relationship: An empirical study on Malaysia. 43000 Selangor, Malaysia.

Thirunavukkarasu, V. A. Sivapalan and K. Rajendra (Dec 2013). Foreign Direct Investment and Economic Growth. Vol. 9, NO. 1; 2014. Sir Lanka.

Hussain AO.M. (2014) The Relationship and Direction of Causality between FDI and Economic Growth in Saudi Arabia. Cape Town, South Africa.

Imen S. M. and A. Zouheir (June 2013). Foreign Direct Investment, Financial development and Economic Growth: Empirical Evidence from North Africans Countries. Tunisia.

Qaiser, A. A.Salman, N.S Ali, AU. Hafiz, N. A. Muhammad (Aug 2011). Impact of foreign Direct Investment on Gross Domestic Product . Vol. 11, Issue 8, Version 1.0. Lahore, Pakistan.

Muhammad K. A. (2007). Foreign Direct Investment and Economic Growth: The Role of Domestic Financial Sector. Islamabad, Pakistan.

Muhammad Z, K. Bakhtiar, Z. Khair (2010). A Nexus between Foreign Direct Investment and Pakistan's Economy. D. I. Khan, Pakistan.

Kashif Y and R. Muhammad (March 2013). The Impact of Foreign Direct Investment on Pakistan Economic Growth. Vol. 4, No 11. Lahore, Pakistan.

Muhammad K. A. and K. A. Shujaat (2011). Foreign Direct Investment and Economic Growth in Pakistan: A Sectoral Analysis. Islamabad, Pakistan.

Najia S, M. Maryam and R. Nabeel (2013). Impact of Foreign Direct Investment on Economic Growth of Pakistan. Vol.3, No.1, Pp 35-45. Karachi, Pakistan.

Amna G. M., C. U. Imran, S. A. Salman (2010). Impact of Foreign Direct Investment on Economic Growth: A case study of Pakistan. Vol. 6, No. 2, Pp 84-92. Karachi, Pakistan.

Najid A, H. F. Muhammad, L. Muhammad, Shafqat Ullah (2012). The causal link between Foreign Direct Investment and Economic Growth in Pakistan. Vol.6. Multan, Pakistan.

Mohammad A. H. (2000). The Determinants of Foreign Direct Investment in Pakistan: An Econometric Analysis. Multan, Pakistan.

Mohsin, A. H. A. Shaista, B. S. Mohammad (Jan, 2004). Foreign Direct Investment, Export and Domestic Output in Pakistan. Islamabad, Pakistan.

Muhammad K. R, S. M. Hazoor, T. H. Safdar, R. K Muhammad (2012). Determinants of Foreign Direct Investment in Pakistan over the period 1975-2011. Vol. 4, No. 8. Faisalabad, Pakistan.

Shumaila H, M. Akhtar, K. Afnan (Jan 2009). Foreign Direct Investment in Telecommunication sector of Pakistan: An Empirical Analysis. D.I. Khan, Pakistan.

Muhammad A. Z., K. Bakhtiar, UZ. Khair (2010). A Nexus between FDI and Pakistan's Economy. D.I. Khan, Pakistan.

Ali R, I.Nasir, A. Zeshan, A. Mohammad, A. Tanvir (Jan 2012). The Role of FDI on Stock Market Development: The case of Pakistan. Vol. 4, No.1. Pakistan. 
Ghulam M (2006). Impact of Foreign Capital Inflows (FCI) on Economic Growth in Pakistan. Lahore, Pakistan.

Zeeshan A, A. H. Mohsin and A. Usman (2004). The Impact of FDI on Economic Growth under Foreign Trade Regimes: A case study of Pakistan. Pp.707718.

Azman W.N.W, L. H. Siong, A. H. Abd (2010). FDI and Economic Growth: New Evidence on the Role of Financial Markets. Malaysia.

Nadeem I., A. Naveed, H. Zeeshan, A. Sonia (2014). Impact of FDI on GDP: A case study from Pakistan. D.G. Khan, Multan, Pakistan.

Niels H., L. Robert (2003). Foreign Direct Investment, Financial Development and Economic growth. Vol.38. Netherlands.

Muhammad I., A. Javaid, K. Yasir, A.N. Sumayya (Jul, 2011). The Causal link between FDI and Economic Growth in Pakistan Economy. Vol.3, No.4. Pakistan.

Mahr Y. M, H. Zakir, A. Nisar (2008). Economic Evaluation of Foreign Direct Investment in Pakistan.Vol.46, No.1. Pp.37-65. Sargodha, Pakistan.

Hafiz Y. S., S. Amir, M. Azeem (April 2014). Impact of Foreign Direct Investment on Economic Growth in Pakistan. Vol. 1(1), Pp. 002-005. Gujranwala, Pkaistan.
Nuzhat F, A. N. Rashid (2010). Impact of Foreign Direct Investment on the Economy of Pakistan since 1980. Islamabad, Pakistan.

Muhammad Z, N. A. Hasnain, F. A. Bashir (2014). Openness and FDI in Pakistan: What Does the Data Tell Us? Vol. 19(12). Pp.1587-1597. Islamabad, Pakistan.

Rana K. A. E., N. A. Muhammad (2010). Economic Determinants of Foreign Direct Investment in Pakistan. Vol.1, No.2. Pp.99-104. Bahawalpur, Pakistan.

Muhammad B., I. Muhammad, A. Amjad, S. Muhammad, A. Mansoor, H. Iltaf, F. Tehreem (2014). Impact of Exchange Rate on Foreign Direct Investment in Pakistan. Vol.2, No.6. Pp.223-231. Layyah, Pakistan,

Anjum A., N. Mohammad (Jan, 2005). The Determinants of Foreign Direct Investment in Pakistan. Karachi, Pakistan.

Zeshan A., S. Rashid, K. M. Kaleem, A. Syedah (2013). Determinants of Foreign Direct Investment in Pakistan's Agriculture Sector. Vol.13, Issue.1.Sahiwal, Pakistan.

Amjad N., S. Ghulam (2006). Trade Openness, FDI and Economic Growth: A Panel Study. Vol.44, No.1. Lahore, Pakistan. 